\title{
Karakterisasi Sifat Fisikokimia dan Fungsional Beras Pecah Kulit Berpigmen dan Tanpa Pigmen
}

\section{Characterization of Physicochemical and Functional Properties of Pigmented and Non-Pigmented Brown Rice}

\author{
Budi Suarti ${ }^{1}$, Sukarno $^{2}$, Ardiansyah ${ }^{3}$, dan Slamet Budijanto ${ }^{2}$
}

\author{
${ }^{1}$ Program Studi Ilmu Pangan, Sekolah Pascasarjana, Departemen Ilmu dan Teknologi Pangan, \\ Fakultas Teknologi Pertanian, IPB University, Dramaga Bogor, 16680 \\ ${ }^{2}$ Departemen IImu dan Teknologi Pangan, Fakultas Teknologi Pertanian, IPB University, \\ Dramaga Bogor, 16680
}

${ }^{3}$ Program studi Teknologi Pangan, Fakultas Teknik dan Ilmu Komputer, Universitas Bakrie, Jakarta, Indonesia E-mail : dsukarno@apps.ipb.ac.id

Diterima: 29 Juli 2020

Revisi: 25 Februari 2021

Disetujui: 30 Maret 2021

\begin{abstract}
ABSTRAK
Beras pecah kulit kaya dengan kandungan gizi dan komponen bioaktif yang bermanfaat bagi kesehatan. Penelitian ini bertujuan untuk mengevaluasi perbedaan karakterisasi sifat fisikokimia, fungsional, dan aktivitas penghambatan $\alpha$-glukosidase beras pecah kulit berpigmen (Cempo Merah dan Jowo Melik) dan tanpa pigmen (Mentik Wangi Susu). Analisis yang dilakukan yaitu warna, proksimat, amilosa, total senyawa fenolik, antosianin, antioksidan, dan inhibisi a-glukosidase. Hasil dari penelitian ini menunjukkan bahwa kandungan total senyawa fenolik dan antosianin lebih tinggi pada beras pecah kulit berpigmen daripada beras tanpa pigmen dengan kadar tertinggi pada varietas Jowo Melik. Aktivitas antioksidan lebih tinggi pada beras pecah kulit berpigmen daripada beras tanpa pigmen, dengan hasil tertinggi pada varietas Cempo Merah. Varietas Cempo Merah memiliki aktivitas inhibitor a-glukosidase yang lebih tinggi daripada varietas Jowo Melik dan Mentik Wangi Susu dengan nilai parameter inhibisi a-glukosidase $\left(\mathrm{IC}_{50}\right)$ masingmasing yaitu $231,66 \mathrm{ppm}, 1.175,89 \mathrm{ppm}$, dan $46.314 \mathrm{ppm}$. Penelitian ini menunjukkan bahwa beras merah varietas Cempo Merah berpotensi untuk dijadikan pertimbangan dalam pengembangan produk pangan bagi penderita diabetes.
\end{abstract}

kata kunci : antosianin, antioksidan, beras pecah kulit, warna, inhibisi $\alpha$-glukosidase

\section{ABSTRACT}

Brown rice is rich in nutritional and bioactive components that are beneficial to health. This study aimed to evaluate the differences in physicochemical characteristics, functional properties, and the a-glucosidase inhibitory activity of pigmented (Cempo Merah and Jowo Melik) and non-pigmented Mentik Wangi Susu brown rice. The analysis carried out in this study was color, proximate contents, amylose, total phenolic compounds content, anthocyanin, antioxidants, and a-glucosidase inhibition. This research showed that total phenolic compounds content and anthocyanin were higher in the pigmented brown rice than in the nonpigmented one. The Jowo Melik variety resulted in the highest yield. The antioxidant activity was highest in the pigmented brown rice than in non-pigmented rice, with the highest yield in the Cempo Merah variety. Cempo Merah variety had the highest inhibitory activity on a-glucosidase $\left(I C_{50} 231.66 \mathrm{ppm}\right)$, while the Jowo melik and Mentik Wangi Susu varieties exhibited lower inhibitory effects with $I C_{50}$ of 1,175.89 and 46,314 ppm, respectively. These results indicated that the red rice Cempo Merah variety could be considered in developing food products for people with diabetes.

keywords: anthocyanins, antioxidants, brown rice, color, $\alpha$-glucosidase inhibitory

\section{PENDAHULUAN}

eras pecah kulit adalah butiran beras utuh yang telah dihilangkan bagian luarnya (sekam) melalui proses penggilingan. Beras pecah kulit mengandung gizi yang tinggi dan juga mengandung beragam komponen bioaktif dibandingkan beras yang disosoh (Reddy, dkk., 2017).

Indonesia memiliki beragam jenis varietas padi yang telah dibudidayakan, termasuk kultivar 
beras berpigmen dan tanpa pigmen. Penentuan beras berpigmen berdasarkan pigmen warna yang ada pada lapisan perikarp biji. Kandungan pigmen beras sangat dipengaruhi oleh berbagai jenis dan jumlah komponen bioaktifnya (Mira, dkk., 2009). Pada umumnya, beras berpigmen seperti beras merah dan hitam mengandung konsentrasi senyawa fenolik yang lebih tinggi dibandingkan beras sosoh (tanpa pigmen) (Shao, dkk., 2014; Shao, dkk., 2018). Selain itu, beras berpigmen juga dilaporkan mengandung komponen antosianin dan proantosianidin yang tinggi (Abdel-Aal, dkk., 2006; Maulani, dkk., 2019, dan Hosoda, dkk., 2018).

Komponen antosianin dilaporkan mampu memperbaiki resistensi insulin, yang merupakan penyebab terjadinya diabetes (Guo, dkk., 2007). Selain itu, diketahui pula komponen bioaktif fenolik dalam beras memiliki efek hipoglikemik dengan menghambat aktivitas a-glukosidase (Jung, dkk., 2007). Namun demikian, jumlah dan komposisi komponen bioaktif dalam beras pecah kulit sangat dipengaruhi oleh perbedaan varietas beras dan lokasi penanaman (Sompong, dkk., 2011). Oleh karena itu, penting melakukan identifikasi kandungan fisikokimia dan fungsional dari berbagai ragam varietas beras.

Potensi varietas beras berpigmen (Cempo Merah dan Jowo Melik), dan beras tanpa pigmen (Mentik Wangi Susu) dari daerah Magelang sebagai antidiabetes diketahui belum ada yang melaporkan. Dengan demikian, perlu diidentifikasi ketiga varietas tersebut untuk mempelajari karakterisasi sifat fisikokimia dan fungsionalnya, serta varietas mana yang terbaik dalam menghambat akitivitas enzim a-glukosidase.

\section{METODOLOGI}

\subsection{Tahapan Penelitian}

\subsubsection{Persiapan Sampel Beras Pecah Kulit}

Bahan yang digunakan pada penelitian ini terdiri dari 3 varietas padi organik yang bersertifikat SNI-2016. Varietas Mentik Wangi Susu (beras putih) dan Cempo Merah (beras merah) dari desa Sawangan, Kecamatan Sawangan, Kabupaten Magelang. Varietas Jowo Melik (beras hitam) diperoleh dari desa Kleteran, Kecamatan Grabak, Kabupaten Magelang, Jawa Tengah.
Padi yang baru dipanen dikeringkan di bawah sinar matahari dan disimpan pada suhu kamar. Gabah beras yang telah kering dinamakan sebagai gabah kering giling (GKG). Sebanyak $2 \mathrm{~kg}$ GKG dari masing-masing varietas digiling dengan mesin husker (Yanmar, HW-60A, Japan) yang menghasilkan beras pecah kulit. Kemudian dihaluskan dan disaring dengan ayakan 100 mesh, lalu beras yang lolos penyaringan 100 mesh disimpan pada suhu $-18^{\circ} \mathrm{C}$ untuk analisis lanjutan.

\subsubsection{Analisis Proksimat}

Pengujian kadar air, abu, protein, lemak, mengacu pada prosedur AOAC (2005). Total protein kasar diperoleh dari hasil perkalian kadar nitrogen dengan faktor protein konversi 5,95 mengunakan metode Kjeldahl. Total Karbohidrat dihitung berdasarkan by difference.

\subsubsection{Analisis Warna}

Pengukuran warna beras pecah kulit menggunakan alat kromameter Minolta dengan mengikuti prosedur Luo, dkk., (2019). Parameter yang diukur meliputi nilai kecerahan $\left(\mathrm{L}^{*}\right)$, redgreenness $(\mathrm{a} *)$, dan yellow-blueness $\left(\mathrm{b}^{*}\right)$.

\subsubsection{Analisis Total Amilosa}

Penentuan total amilosa berdasarkan prosedur AACC (1999). Etanol (95 persen) (K49350783 739, Merck) sebanyak $1 \mathrm{~mL}$ dan larutan $\mathrm{NaOH}$ (1 N) (B0881298 309, Merck), $9 \mathrm{~mL}$ ditambahkan ke $100 \mathrm{mg}$ sampel tepung. Setelah pencampuran, sampel dipanaskan selama 10 menit dalam waterbath pada suhu $100^{\circ} \mathrm{C}$ untuk menggelatinisasikan pati. Sampel didinginkan dan dipindahkan ke labu volumetrik $100 \mathrm{~mL}$. Kemudian diambil $5 \mathrm{~mL}$ larutan pati dan ditambahkan $1 \mathrm{~mL}$ larutan asam asetat $(1$ $\mathrm{N})$. Setelah itu, ditambahkan $2 \mathrm{~mL}$ larutan iod, volume disesuaikan hingga $100 \mathrm{~mL}$ dengan akuades, dicampur, dan didiamkan selama 20 menit. Absorbansi diukur pada $620 \mathrm{~nm}$ menggunakan spektrofotometer UV-visible (Genesis 150).

\subsubsection{Persiapan Ekstrak Sampel}

Persiapan ekstrak sampel mengikuti metode Reddy, dkk., (2017) yang dimodifikasi sedikit dengan jumlah pelarut yang berbeda. Sampel 
ditambahkan pelarut metanol (1:10), dan diaduk selama 3 jam menggunakan shaker orbital. Selanjutnya sampel disentrifugasi selama 20 menit pada $3000 \mathrm{rpm}$. Supernatan yang terbentuk dipisahkan dengan kertas saring Whatman 42. Ekstrak yang dihasilkan kemudian disimpan pada suhu $-18^{\circ} \mathrm{C}$ untuk analisis total senyawa fenolik dan antioksidan.

\subsubsection{Analisis Total Senyawa Fenolik}

Pengujian total senyawa fenolik mengacu prosedur Razak, dkk. (2015) dengan metode Folin-Ciocalteu. Ekstrak sampel $1 \mathrm{~mL}$ direaksikan dengan reagen Folin-Ciocalteu 5 $\mathrm{mL}$, dan larutan natrium karbonat (7,5 persen) 4 $\mathrm{mL}$, lalu diinkubasi selama 2 jam di suhu ruang. Selanjutnya absorbansi sampel diukur pada $765 \mathrm{~nm}$ menggunakan spektrofotometer UV/ Vis (Genesis 150). Asam galat (G-7384, Sigma) digunakan sebagai standar. Total senyawa fenolik dinyatakan sebagai miligram ekuivalen asam galat (GAE) per gram sampel (mg GAE/g sampel).

\subsubsection{Analisis Aktivitas Antioksidan}

Pengujian 1,1-Diphenyl-2-picryhydrazyl (DPPH) mengikuti modifikasi prosedur BrandWilliams, dkk. (1995) dengan sedikit modifikasi. Sampel ekstrak sebanyak $100 \mu \mathrm{L}$ direaksikan dengan $3,9 \mathrm{~mL}$ larutan DPPH dalam metanol (100 $\mu \mathrm{mol} / \mathrm{L})$. Campuran tersebut divorteks dan selanjutnya diinkubasi selama 2 jam. Absorbansi (A) sampel diukur menggunakan spektrofotometer UV/Vis pada panjang gelombang $515 \mathrm{~nm}$. Kontrol terdiri dari metanol dan DPPH. Aktivitas antioksidan dinyatakan dalam mg ekuivalen dengan trolox.

\subsubsection{Analisis Total Antosianin}

Pengujian total antosianin berdasarkan metode $\mathrm{pH}$ diferensial dengan mengikuti prosedur Giusti dan Wrolstad (2001). Sampel 1 $\mathrm{g}$ dicampur dengan $10 \mathrm{~mL}$ metanol yang telah diasamkan sebelumnya (perbandingan metanol: $1 \mathrm{M} \mathrm{HCl}$ yaitu 85:15, v/v), lalu disentrifugasi 3000 rpm selama 20 menit di suhu ruang.

Ekstrak sampel $100 \mu \mathrm{L}$ dicampur masingmasing dengan $5 \mathrm{~mL}$ buffer kalium klorida $\mathrm{pH}$ 1,0 , dan buffer natrium asetat $\mathrm{pH} 4,5$. Kemudian divorteks dan didiamkan selama 15 menit. Absorbansi sampel diukur pada 510 dan 700 $\mathrm{nm}$ terhadap air suling dalam spektrofotometer UV/Vis.

Kandungan antosianin ( $\mathrm{mg} / \mathrm{g}$ sampel) $=$

A $x$ MW $\times$ DF $\times 100 /(e \times 1) .$.

Keterangan:

$$
\begin{aligned}
\mathrm{A}= & \mathrm{A}[(\mathrm{A} 510-\mathrm{A} 700) \mathrm{pH} 1,0-(\mathrm{A} 510-\mathrm{A} 700) \\
& \text { pada } \mathrm{pH} 4,5] \\
\mathrm{MW}= & \text { berat molekul sianidin-3-glukosida } \\
& (449,2) \\
\mathrm{DF}= & \text { faktor pengenceran sampel } \\
\varepsilon= & \text { absorpsi molar dari sianidin-3- } \\
& \text { glukosida }(26.900) .
\end{aligned}
$$

\subsubsection{Analisis Inhibisi a-glukosidase}

Pengukuran penghambatan enzim a-glukosidase mengikuti prosedur Sancheti, dkk. (2009). Campuran larutan reaksi yang terdiri dari $50 \mu \mathrm{L}$ buffer fosfat $(0,1 \mathrm{M}, \mathrm{pH} 7,0)$, $25 \mu \mathrm{L}$ 4-nitrofenil $\alpha$-D-glukopiranosida $(0,5$ $\mathrm{mM}$ ) (dilarutkan dalam buffer fosfat $0,1 \mathrm{M}, \mathrm{pH}$ 7,0), $10 \mu \mathrm{L}$ sampel uji (konsentrasi $500 \mu \mathrm{g} /$ $\mathrm{mL}$ ), dan $25 \mu \mathrm{L}$ larutan a-glukosidase (G5003, Sigma) diinkubasi selama 30 menit pada suhu $37^{\circ} \mathrm{C}$. Selanjutnya reaksi dihentikan dengan penambahan $100 \mu \mathrm{L}$ larutan natrium karbonat $(0,2 \mathrm{M})$. Pengukuran hidrolisis enzimatis pada substrat yaitu dengan cara menghitung jumlah p-nitrofenol yang terlepas di dalam larutan reaksi dengan menggunakan microplate reader pada panjang gelombang $410 \mathrm{~nm}$. Penelitian ini menggunakan akarbosa sebagai kontrol positif.

\subsection{Analisis Statistik}

Data yang ditampilkan adalah rata-rata \pm SD dengan jumlah ulangan 2. Data tiga varietas ini dianalisis warna, kandungan proksimat, amilosa, total senyawa fenolik, total antosianin, aktivitas antioksidan, dan inhibisi a-glukosidase dengan Analysis of Variance (ANOVA) mengunakan software IBM Statistic SPSS versi 25 (Chicago, IL, USA). Apabila terdapat perbedaan hasil ANOVA, maka dilakukan uji lanjutan Duncan dengan taraf 5 persen.

\section{HASIL DAN PEMBAHASAN}

\subsection{Komposisi Kimia}

Komposisi kimia beras pecah kulit tanpa pigmen dan berpigmen disajikan pada Tabel 1. 
Kandungan kadar air pada ketiga varietas beras berkisar 10,85-11,23 persen. Kisaran nilai kadar air tersebut masih berada di bawah 14 persen, sehingga dapat terhindar dari kerusakan dan penurunan mutu selama penyimpanan.

Tabel 1. menunjukkan beras berpigmen Cempo Merah lebih tinggi secara nyata $(p<0,05)$ terhadap beras lainnya dalam hal kandungan air, protein, dan abu. Sedangkan kandungan
Beras sebagian besar tersimpan dalam bentuk pati (Susiyanti, dkk., 2020). Pati tersusun dari amilosa dan amilopektin. Amilosa adalah polimer glukosa dengan stuktur rantai lurus dan terikat pada ikatan $\alpha-(1,4)-D-g l i k o s i d a$. Varietas Jowo Melik memiliki kandungan amilosa yang lebih tinggi (26,32 persen), dibandingkan varietas Cempo Merah (24,75 persen) dan Mentik Wangi Susu (20,71 persen) (Tabel 1). Berdasarkan tingkat kandungan amilosa, kedua

Tabel 1. Komposisi Kimia Beras Pecah Kulit Berpigmen dan Tanpa Pigmen

\begin{tabular}{lccc}
\hline \multirow{2}{*}{ Parameter } & $\begin{array}{c}\text { Tanpa Pigmen } \\
\text { Mentik Wangi Susu }\end{array}$ & \multicolumn{2}{c}{ Berpigmen } \\
\cline { 2 - 4 } & $10,85 \pm 0.19^{\mathrm{a}}$ & $11,23 \pm 0.17^{\mathrm{b}}$ & $11,09 \pm 0.26^{\mathrm{ab}}$ \\
\hline Air (\%) & $9,15 \pm 0,19^{\mathrm{a}}$ & $11,20 \pm 0,11^{\mathrm{c}}$ & $9,72 \pm 0,09^{\mathrm{b}}$ \\
Protein (\% bk) & $3,97 \pm 0,03^{\mathrm{b}}$ & $3,60 \pm 0,12^{\mathrm{a}}$ & $4,49 \pm 0,14^{\mathrm{c}}$ \\
Lemak (\% bk) & $2,60 \pm 0,09^{\mathrm{a}}$ & $2,97 \pm 0,04^{\mathrm{b}}$ & $2,64 \pm 0,06^{\mathrm{a}}$ \\
Abu (\% bk) & $73,44 \pm 0,16^{\mathrm{c}}$ & $71,01 \pm 0,35^{\mathrm{a}}$ & $72,05 \pm 0,21^{\mathrm{b}}$ \\
Karbohidrat (\% bk) & $20,71 \pm 0,15^{\mathrm{a}}$ & $24,75 \pm 0,44^{\mathrm{b}}$ & $26,32 \pm 0,60^{\mathrm{c}}$ \\
Amilosa (\% bk) & &
\end{tabular}

Keterangan : Nilai dengan huruf berbeda yang ditampilkan pada kolom tabel yang sama menunjukkan perbedaan signifikan $(p<0,05) ; n=2$.

karbohidrat tertinggi secara nyata ditunjukkan pada beras tanpa pigmen Mentik Wangi Susu. Tingginya kandungan abu merepresentasikan banyaknya jumlah mineral yang terkandung dalam beras (Verma dan Srivastav, 2017). Kadar protein ini berbeda dengan yang dilaporkan oleh beberapa peneliti lain (Alves, dkk., 2016; Saragih, dkk., 2019). Saragih, dkk. (2019) melaporkan beras hitam mengandung kadar protein yang lebih tinggi, diikuti beras merah, dan putih dengan masing-masing sebesar 8,10 persen, 7,30 persen, dan 7,10 persen. Perbedaan kandungan kadar protein ini dipengaruhi oleh beberapa faktor, yaitu penanganan pasca-panen, kultivar, dan faktor lingkungan (Verma dan Srivastav, 2017).

Pada hasil pengujian kadar lemak, diperoleh nilai kisaran kadar lemak dari ketiga varietas tersebut yaitu 3,60-4,49. Varietas Jowo Melik mengandung kadar lemak tertinggi $(p<0,05)$. Hasil yang diperoleh hampir serupa dengan yang dilaporkan oleh Alves, dkk. (2016), kandungan lemak dalam beras yaitu berkisar 2,3-5,1 persen dengan beras hitam mengandung kadar lemak tertinggi (5,1 persen). Kandungan lemak dalam beras diketahui terakumulasi di dalam bagian lapisan aleuron dan embrio (Khin, dkk., 2013). varietas Cempo Merah dan Mentik Wangi Susu diklasifikasikan ke dalam beras dengan kadar amilosa sedang yang menurut SNI (2013), beras dengan kadar amilosa sedang (20-25 persen) menghasilkan tekstur nasi yang pulen. Sementara itu, beras dengan kadar amilosa tinggi (>25 persen) menghasilkan tekstur nasi yang keras/pera. Hal tersebut disebabkan oleh terjadinya retrogradasi pada molekul amilosa (Sompong, dkk., 2011). Hasil penelitian ini menunjukkan varietas Jowo Melik tergolong ke dalam beras dengan kandungan amilosa tinggi.

\subsection{Komponen Fitokimia}

Hasil analisis kandungan fitokimia dan aktivitas antioksidan beras pecah kulit berpigmen dan tanpa pigmen disajikan pada Tabel 2.

Hasil menunjukkan kandungan total senyawa fenolik (TSF) dan total antosianin pada beras berpigmen Jowo Melik lebih tinggi secara nyata $(p<0,05)$ dibandingkan beras lainnya. Hal serupa juga dilaporkan oleh Shao, dkk. (2014), total fenolik dalam beras hitam lebih tinggi dibandingkan beras merah dan putih dengan kandungan masing-masing sebesar 0,437 mg GAE/g, 0,421 mg GAE/g, dan 0,167 $\mathrm{mg}$ GAE/g. Tingginya kandungan fenolik dalam 
Tabel 2. Komponen Fitokimia dan Aktivitas Antioksidan Beras Pecah Kulit Berpigmen dan Tanpa Pigmen

\begin{tabular}{lccc}
\hline \multicolumn{1}{c}{ Parameter } & Tanpa pigmen & \multicolumn{2}{c}{ Berpigmen } \\
\cline { 2 - 4 } & Mentik Wangi Susu & Cempo Merah & Jowo Melik \\
\hline Total Senyawa fenolik (mg/g bk) & $2,33 \pm 0,04^{\mathrm{a}}$ & $3,27 \pm 0,10^{\mathrm{b}}$ & $4,38 \pm 0,12^{\mathrm{c}}$ \\
Total Antosianin (mg/g bk) & $0,05 \pm 0,00^{\mathrm{a}}$ & $0,21 \pm 0,01^{\mathrm{b}}$ & $2,33 \pm 0,06^{\mathrm{c}}$ \\
Aktivitas antioksidan (TEAC mg/g bk) & $0,83 \pm 0,01^{\mathrm{a}}$ & $2,94 \pm 0,01^{\mathrm{c}}$ & $1,89 \pm 0,03^{\mathrm{b}}$ \\
\hline
\end{tabular}

Keterangan : Nilai dengan huruf berbeda yang ditampilkan pada kolom tabel yang sama berbeda signifikan $(p<0,05) ; n=2$

beras hitam diduga karena lapisan perikarp pada beras hitam lebih tebal. Hal tersebut sesuai dengan hasil penelitian Alves, dkk. (2016) ditemukan dari hasil scanning mikroskop elektron, lapisan perikarp pada beras hitam lebih tebal dibandingkan pada beras merah, dan juga kandungan senyawa fenolik lebih banyak terdapat dalam beras hitam yang diekstraksi dengan Aseton/Air (70:30) dibandingkan pada beras merah. Lapisan perikarp dilaporkan banyak mengandung komponen fenolik (Alves, dkk., 2016).

Pada hasil analisis antosianin, beras berpigmen yang mengandung antosianin tertinggi terdapat pada varietas Jowo Melik. Kandungan antosianin dalam varietas Jowo Melik tinggi karena varietas tersebut termasuk kelompok beras hitam yang memiliki pigmen polifenol utama berupa antosianin. Menurut Sompong, dkk. (2011) dan Shao, dkk. (2018), komponen antosianin yang terdapat dalam beras hitam adalah sianidin-3-glukosida dan peonidin-3-glukosida, dimana kandungan ini lebih dominan pada beras hitam daripada beras merah dan tanpa pigmen.

Penelitian ini juga sesuai dengan laporan Abdel-Aal, dkk. (2006), bahwa beras hitam mengandung senyawa antosianin 35 kali lipat lebih tinggi dibandingkan beras merah dengan jumlah masing-masing yaitu $3276 \mu \mathrm{g} / \mathrm{g}$ dan 94 $\mu \mathrm{g} / \mathrm{g}$. Sementara itu, beras putih dilaporkan mengandung antosianin yang sangat rendah dengan kisaran $0,64-0,93 \mathrm{mg} / 100 \mathrm{~g}$ dari beberapa varietas beras cokelat (Maulani, dkk., 2019).

Beras berpigmen mengandung aktivitas antioksidan yang lebih tinggi daripada tanpa pigmen, di mana beras pecah kulit berpigmen merah yaitu varietas Cempo Merah mengandung aktivitas antioksidan lebih tinggi daripada beras berpigmen hitam (varietas Jowo Melik), hal ini kemungkinan disebabkan oleh perbedaan kandungan senyawa fenolik terikat dan flavonoid

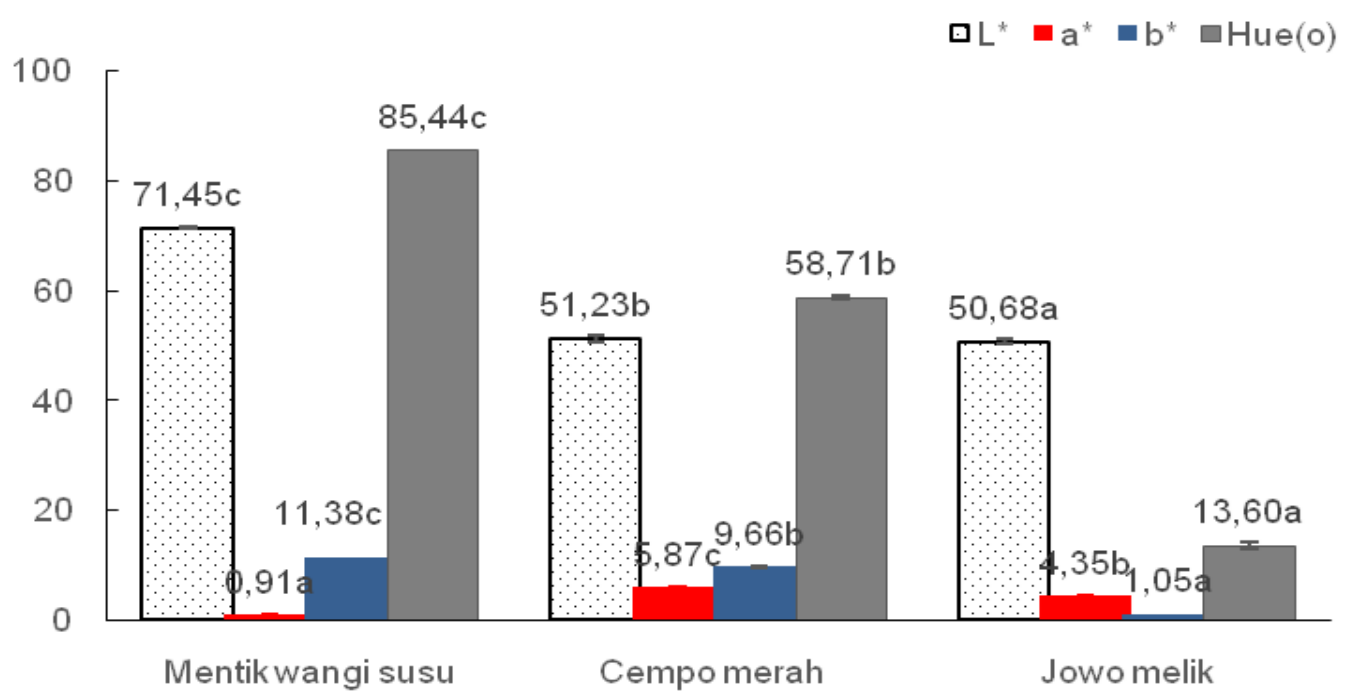

Gambar 1. Analisis Warna Beras Pecah Kulit. Nilai yang diikuti dengan huruf berbeda menunjukkan berbeda Signifikan $(p<0,05) ; n=2$ 
pada beras pecah kulit. Menurut Yuliana dan Akhbar (2020), peningkatan antioksidan berkaitan dengan flavonoid pada beras, yang menunjukkan korelasi positif yang lebih kuat $(r$ $=0,870)$. Analisis korelasi juga menunjukkan bahwa aktivitas antioksidan berkorelasi positif dengan kandungan fenolik $(r=0.886)$ dan antosianin ( $r=0,650)$ (Murdifin, dkk., 2015).

Selain itu, peningkatan aktivitas antioksidan mungkin saling berkaitan dengan kandungan proantosianidin yang pada beras merah. Hal tersebut sesuai dengan laporan hasil penelitian Hosoda, dkk. (2018), kandungan total proantosianidin dalam beras merah sangat signifikan $(p<0,001)$ lebih tinggi dibandingkan dalam beras hitam dan beras tanpa pigmen. Tingginya kandungan proantosianidin dalam beras merah disebabkan oleh pigmen proantosinidin yang merupakan pigmen utama dalam beras merah (Hosoda, dkk., 2018).

Pigmen proantosianidin dilaporkan berkorelasi positif terhadap nilai total antioksidan (Hosoda, dkk., 2018; Shao, dkk., 2018). Tambahan lainnya, senyawa fenolik dan pigmen antosianin juga dilaporkan berkorelasi positif dengan antioksidan (Hosoda, dkk., 2018; Sompong, dkk., 2011; Shao, dkk., 2018;). Selain itu, komponen bioaktif seperti $y$-oryzanol, tokotrienol, dan tokoferol dilaporkan juga berperan penting dalam meningkatkan aktivitas antioksidan (lqbal dkk., 2005). Beras merah varietas Cempo Merah diduga mengandung komponen-komponen bioaktif tersebut.

\subsection{Warna}

Hasil analisis warna biji beras pecah kulit berpigmen dan tanpa pigmen disajikan pada Gambar 1. Hasil menunjukkan beras tanpa pigmen Mentik Wangi Susu lebih tinggi secara nyata $(p<0,05)$ terhadap beras lainnya dalam hal Nilai $L^{*}$, sedangkan beras berpigmen Cempo Merah mengandung Nilai $a^{*}$ lebih tinggi daripada varietas lainnya. Sedangkan Nilai $b^{*}$ dan hue lebih rendah pada beras berpigmen Jowo Melik daripada varietas lainnya. Nilai $L^{*}$ menunjukkan tingkat kecerahan sampel. Semakin kecil nilai $L^{*}$, maka warna sampel semakin gelap. Nilai $a^{*}$ menunjukkan perbedaan warna antara merahhijau dan nilai $b^{*}$ menunjukkan perbedaan antara kuning dan biru. Semakin rendah nilai $a^{*}$ dan $b^{*}$ menunjukan warna sampel yang semakin hijau dan biru.

Nilai $L^{*}, a^{*}, b^{*}$, hue tersebut berkaitan dengan keberadaan komponen bioaktif di dalam sampel beras. Hal tersebut didukung oleh hasil penelitian Shao, dkk., (2018), ditemukan adanya korelasi negatif antara total kandungan fenolik dan senyawa komposisi antosianin (peonidin3-O-glukosida dan peonidin-3-glukosida) terhadap nilai $L^{*}, b^{*}$, dan hue $\left(^{\circ}\right)$. Makna dari korelasi negatif tersebut yaitu semakin tinggi kandungan total fenolik dan antosianin di dalam sampel, maka semakin rendah nilai $L^{*}, b^{*}$, dan hue $\left(^{\circ}\right)$. Hal tersebut sesuai dengan hasil penelitian yang diperoleh yaitu varietas Jowo melik mengandung total fenolik dan antosianin tertinggi (Tabel 2).

Pada varietas Cempo Merah menunjukkan pula nilai parameter warna $\mathrm{L}^{*}, \mathrm{~b}^{*}$, dan $h u e\left(^{\circ}\right)$ yang lebih rendah dibandingkan varietas Mentik Wangi Susu. Hal tersebut seiring dengan kandungan senyawa fenolik dan antosianin yang lebih tinggi dalam varietas Cempo Merah.

Tambahan lainnya, senyawa proantosianidin dilaporkan memengaruhi nilai parameter warna $a^{*}$. Menurut laporan Shao, dkk. (2018), keberadaan senyawa proantosianidin yang tinggi pada beras merah berpengaruh terhadap besaran nilai $a^{*}$ dengan nilai koefisien korelasi yang dihasilkan yaitu $r=0,86(p<0,001)$. Hal tersebut sesuai dengan hasil penelitian yang diperoleh, yaitu varietas Cempo Merah menghasilkan nilai warna $a^{*}$ yang lebih tinggi, serta senyawa proantosianidin yang lebih tinggi dibandingkan kedua varietas tersebut.

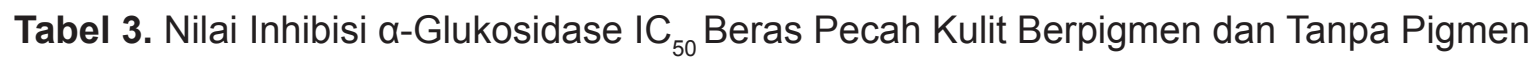

\begin{tabular}{lccc}
\hline \multicolumn{1}{c}{ Parameter } & Tanpa Pigmen & \multicolumn{2}{c}{ Berpigmen } \\
\cline { 3 - 4 } & Mentik Wangi Susu & Cempo Merah & Jowo Melik \\
\hline Inhibisi & $46314 \pm 175,45^{\mathrm{C}}$ & $231,66 \pm 0,46^{\mathrm{a}}$ & $1175,89 \pm 24,49^{\mathrm{b}}$ \\
a-glukosidase $\mathrm{IC}_{50}(\mathrm{ppm})$ & & & \\
\hline
\end{tabular}

Keterangan: Nilai dengan huruf berbeda yang ditampilkan pada kolom tabel yang sama berbeda signifikan $(p<0,05) ; n=2$. Nilai IC ${ }_{50}$ akarbosa (kontrol positif) adalah 0,23 ppm 


\subsection{Inhibisi $\alpha$-glukosidase}

Tabel 3 menunjukkan nilai inhibisi a-glukosidase yang berbeda nyata $(p<0,05)$ dibandingkan ketiga varietas dengan nilai $I_{50}$ tertinggi ada pada varietas beras tanpa pigmen Mentik Wangi Susu, hal ini menunjukkan bahwa beras pecah kulit tanpa pigmen kurang berpotensi sebagai pangan antidiabetes daripada beras berpigmen.

Enzim a-glukosidase merupakan enzim yang berperan dalam metabolisme karbohidrat di dalam usus. Enzim ini dapat menghidrolisis pati menjadi glukosa untuk selanjutnya diserap selama proses pencernaan (Balakrishnan, dkk., 2019; Phoboo, dkk., 2015). Penghambatan enzim ini menguntungkan karena mampu mengontrol kelebihan jumlah glukosa yang ada dalam darah, selain itu diketahui pula dapat mengendalikan hiperglikemia yang merupakan penyebab terjadinya Diabetes tipe II (Phoboo, dkk., 2015).

Penghambatan aktivitas enzim a-glukosidase dapat diamati dari nilai $\mathrm{IC}_{50}$ yang diartikan sebagai kemampuan beras pecah kulit dalam menghambat 50 persen enzim $\alpha$-glukosidase pemecah pati. Tingginya nilai IC $\mathrm{C}_{50}$ dalam varietas Mentik Wangi Susu memberikan gambaran akan sifat varietas tersebut, yaitu aktivitas penghambatan terhadap enzim a-glukosidase semakin rendah.

Dengan demikian, semakin kecil nilai $\mathrm{IC}_{50}$ pada beras berpigmen varietas Cempo Merah menunjukkan aktivitas penghambatan terhadap enzim $\alpha$-glukosidase semakin tinggi. Hal ini menginterpretasikan bahwa beras merah varietas Cempo Merah berpotensi sebagai pangan antidiabetes yang lebih baik daripada beras hitam varietas Jowo Melik, dan beras tanpa pigmen varietas Mentik Wangi Susu. Ini diduga karena aktivitas antioksidan dan proantosianidin pada varietas Cempo Merah lebih tinggi dibandingkan kedua varietas tersebut.

Hal tersebut juga didukung oleh Lee, dkk. (2007) yang menyatakan bahwa senyawa polimer dan oligomer proantosianidin dari kulit kesemek mampu menurunkan aktivitas enzim a-glukosidase yaitu masing-masing 74,0 persen, dan 97,4 persen pada konsentrasi $100 \mu \mathrm{g} / \mathrm{mL}$. Selain itu, Hsu, dkk. (2008) juga melaporkan yang serupa, senyawa proantosianidin dari ekstrak daun Chamaecyparis obtusa var. formosana efektif menghambat aktivitas a-glukosidase. Namun demikian, perlu dilakukan identifikasi senyawa proantosianidin dari beras merah untuk mengetahui nilai aktivitas penghambatan $\alpha$ - glukosidase. Hasil penelitian menunjukkan akarbosa lebih efektif menghambat $\alpha$-glukosidase pada nilai $I_{50}$ yang lebih rendah yaitu 0,23 ppm. Hal tersebut diduga karena akarbosa merupakan senyawa murni. Secara umum akarbosa digunakan untuk mengobati hiperglikemia postprandial pada penderita Diabetes tipe II, namun juga telah banyak dilaporkan dapat menimbulkan berbagai efek samping seperti sakit perut, perut kembung, dan diare. Berbeda dengan penelitian ini, beras pecah kulit tidak menimbulkan efek samping karena dapat dikonsumsi sebagai makanan.

\section{KESIMPULAN}

Sifat fisikokimia dan fungsional beras pecah kulit berpigmen lebih tinggi daripada beras tanpa pigmen. Beras pecah kulit berpigmen hitam (Jowo Melik) mengandung total senyawa fenolik, dan antosianin lebih tinggi daripada beras berpigmen merah (Cempo Merah).

Beras pecah kulit merah lebih berpotensi sebagai antidiabetes daripada beras pecah kulit hitam, sehingga berpotensi untuk dijadikan pertimbangan dalam pembuatan produk pangan bagi penderita diabetes.

\section{UCAPAN TERIMA KASIH}

Terima kasih kami ucapkan kepada Beasiswa Unggulan Dosen Indonesia, LPDP atas pendanaan untuk pelaksanaan penelitian.

\section{DAFTAR PUSTAKA}

[AACC] American Association of Cereal Chemists. 1999. AACC International Method. 1999. 61-03.01: Amylose Content of Milled Rice. Minnesota (US): American Association of Cereal Chemists.

[AOAC] Association of Official Analytical Chemistry. 2005. Official methods of analysis of AOAC International 18th edition. AOAC International.

Abdel-Aal, E. S. M., J. C. Young, I. Rabalski. 2006. Anthocyanin Composition in Black, Blue, Pink, Purple, and Red Cereal Grains. Journal of Agricultural and Food Chemistry. Vol. 54:46964704. 
Alves, G. H., C. D. Ferreira, P. G. Vivian, J. L. F. Monks, M. C. Moacir Cardoso Elias, N. L Vanier, M. de. Oliveira. 2016. The Revisited Levels of Free and Bound Phenolics in Rice: Effects of The Extraction Procedure. Food Chemistry. Vol. 208. Oct:116-123.

Balakrishnan, J., S. K. Thamilarasan, M. S Ravi, A. Pugazhendhi, V. Perumal, I. A. Padikasan. 2019. Comparison of Phytochemicals, Antioxidant and Hypoglycemic Activity of Four Different Brown Rice Varieties. Biocatalysis and Agricultural Biotechnology. Vol. 21. Sep: 1-6.

Brand-Williams, W., and M. E. B. C. Cuvelier, 1995. Use of Free Radical Method to Evaluate Antioxidant Activity. Lebensm Wiss Technology. Vol.28: 25-30.

Giusti, M. M., and R. E. Wrolstad. 2001. Characterization and Measurement of Anthocyanins by UV-Visible Spectroscopy. In: Giusti, M.M., Wrolstad, R.E. (Eds.), Current Protocols in Food Analytical Chemistry. New York: John Wiley \& Sons, Inc.

Guo, H., W. Ling, Q. Wang, C. Liu, Y. Hu, M. Xia, X. Feng, X. Xia. 2007. Effect of Anthocyanin-Rich Extract from Black Rice (Oryza sativa L. indica) on Hyperlipidemia and Insulin Resistance in Fructose-Fed Rats. Plant Foods for Human Nutrition. Vol. 62. Mar: 1-6.

Hosoda, K., H. Sasahara, K. Matsushita, Y. Tamura, M. Miyaji, H. Matsuyama. 2018. Anthocyanin and Proanthocyanidin Contents, Antioxidant Activity, and In Situ Degradability of Black and Red Rice Grains. Asian-Australasian Journal of Animal Sciences. Vol. 31. Aug: 1213-1220.

Hsu, C. Y., G. M. Lin, H. Y. Lin, S. T. Chang. 2008. Characteristics of Proanthocyanidins in Leaves of Chamaecyparis Obtusa var. Formosana as Strong a-Glucosidase Inhibitors. Journal of The Science of Food and Agriculture. Vol. 98. Aug: 3806-3814.

Iqbal, S., M. I. Bhanger, F. Anwar. 2005. Antioxidant Properties and Components of Some Commercially Available Varieties of Rice Bran in Pakistan. Food Chemistry. Vol. 93. Nov: 265272.

Jung, E. H., S. R. Kim, I. K. Hwang, T. Y. Ha. 2007. Hypoglycemic Effects of a Phenolic Acid Fraction of Rice Bran and Ferulic Acid in C57BL/ $\mathrm{KsJ}-d b / d b$ Mice. Journal of Agricultural and Food Chemistry. Vol. 55. Nov: 9800-9804.

Khin, O. M., M. Sato, T. Li-Tao, Y. Matsue, A. Yoshimura, T. Mochizuki. 2013. Close Association between Aleurone Traits and Lipid Contents of Rice Grains Observed in Widely Different Genetic Resources of Oryza sativa. Plant Production Science. Vol. 16(1): 41-49.
Lee, Y. A., E. J. Cho, T. Tanaka, T. Yokozawa. 2007. Inhibitory Activities of Proanthocyanidins from Persimmon Against Oxidative Stress and Digestive Enzymes Related to Diabetes. Journal of Nutritional Science and Vitaminology. Vol. 53. Jun:287-292.

Luo, X., Y. Li, D. Yang, J. Xing, K. Li, M. Yang, Z. Chen. 2019. Effects of Electron Beam Irradiation on Storability of Brown and Milled Rice. Journal of Stored Products Research. Vol. 81. Mar:2230.

Maulani, R. R., D. Sumardi, A. Pancoro. 2019. Total Flavonoids and Anthocyanins Content of Pigmented Rice. Drug Invention Today. Vol. 12(2): 369-373.

Mira, N. V. M., I. L. Massaretto, C. de S.C. I. Pascual and U. M. Lanfer Marquez. 2009. Comparative study of phenolic compounds in different Brazilian rice (Oryza sativa L.) genotypes. Journal of Food Composition and Analysis. Vol. 22. Aug: 405-409.

Murdifin, M., E. Pakki, A Rahim, S. A Syaiful, Ismail, Y. M. Evary, and M. Akbar Bahar. 2015. Physicochemical properties of indonesian pigmented rice (Oryza sativa linn.) varieties from south sulawesi. Asian Journal of Plant Sciences, 14(2), 59-65. https://doi.org/10.3923/ ajps.2015.59.65.

Phoboo, S., K. Shetty, T. E. E Abdelkhalig. 2015. In Vitro Assays of Anti-diabetic and Antihypertensive Potential of Some Traditional Edible Plants of Qatar. Journal of Medicinally Active Plants. Vol. 4. Jan:3-4.

Razak, D. L., N. Y. Abd Rashid, A. Jamaluddin, S. A. Sharifudin, K. Long. 2015. Enhancement of Phenolic Acid Content and Antioxidant Activity of Rice Bran Fermented with Rhizopus oligosporus and Monascus purpureus. Biocatalysis and Agricultural Biotechnology. Vol. 4. Jan: 33-38.

Reddy, C. K., L. Kimi, S. Haripriya, N. Kang. 2017. Effects of Polishing on Proximate Composition, Physico- Chemical Characteristics, Mineral Composition and Antioxidant Properties of Pigmented Rice. Rice Science. Vol. 24. Sep: 241-252.

Sancheti, S., S. Sancheti, S. Yum-sung. 2009. Chaenomeles Sinensis: A Potent $\alpha$-and $\beta$ -Glucosidase Inhibitor. American Journal of Pharmacology and Toxicology. Vol. 4(1): 8-11.

Saragih, B., N. M. Naibaho, B. Saragih. 2019. Nutritional, Functional Properties, Glycemic Index and Glycemic Load of Indigenous Rice from North and East Borneo. Food Research. Vol. 3. Oct: 537-545.

Shao, Y., Z. Hu, Y. Yu, R. Mou, Z. Zhu, T. Beta. 2018. Phenolic acids, anthocyanins, proanthocyanidins, 
antioxidant activity, minerals and their correlations in non-pigmented, red, and black rice. Food Chemistry. Vol. 239. Jan: 733-741

Shao, Y., F. Xu, X Sun, J. Bao, T. Beta. 2014. Identification and Quantification of Phenolic Acids and Anthocyanins as Antioxidants in Bran, Embryo and Endosperm of White, Red and Black Rice Kernels (Oryza sativa L.). Journal of Cereal Science. Vol. 59. Mar: 211-218.

[SNI] Standar Nasional Indonesia. 2013. Beras SNI 6128:2008. Jakarta (ID): Badan Standardisasi Nasional.

Sompong, R., S. Siebenhandl-Ehn, G. LinsbergerMartin, E. Berghofer. 2011. Physicochemical and antioxidative properties of red and black rice varieties from Thailand, China and Sri Lanka. Journal of Agricultural and Food Chemistry. Vol. $124: 132-140$.

Susiyanti, Rusmana, Y. Maryani, Sjaifuddin, N. Krisdianto, M. A. Syabana. 2020. The Physicochemical Properties of Several Indonesian Rice Varieties. BIOTROPIA. Vol. 27 (1): 41-50.

Verma, D.K., P.P Srivastav. 2017. Proximate Composition, Mineral Content and Fatty Acids Analyses of Aromatic and Non-Aromatic Indian Rice. Rice Science. Vol. 24. Jan: 21-31.

Yuliana, N. D., dan M. A. Akhbar. 2020. Chemical and physical evaluation, antioxidant and digestibility profiles of white and pigmented rice from different areas of Indonesia. Brazilian Journal of Food Technology, 23, 1-13. https:// doi.org/10.1590/1981-6723. 23818 .

\section{BIODATA PENULIS:}

Budi Suarti dilahirkan di Medan, pada tanggal 20 maret 1977. Penulis menyelesaikan pendidikan S1 Teknologi Hasil Pertanian, Universitas Muhammadiyah Sumatera Utara tahun 1999, S2 Kimia, Universitas Sumatera Utara tahun 2003 dan sekarang sedang melanjutkan studi di IImu Pangan, Institut Pertanian Bogor.

Slamet Budijanto dilahirkan di Madiun, pada tanggal 2 Mei 1961. Penulis menyelesaikan pendidikan S1 (Food Technology, Bogor Agricultural University, Indonesia) tahun 1985, S2 Food chemistry, Tohoku University, Japan tahun 1990, dan S3 Food chemistry, Tohoku University, Japan tahun 1993.

Sukarno dilahirkan di Pati, pada tanggal 27 Oktober 1960. Penulis menyelesaikan pendidikan S1 (Food Technology, Bogor Agricultural University, I) tahun 1985, S2 Food chemistry, Hokkaido University, Japan tahun 1993 dan S3 Food chemistry, Hokkaido University, Japan tahun 1996.

Ardiansyah dilahirkan di Sambas, pada tanggal 18 Oktober 1975. Penulis menyelesaikan pendidikan AMa., Food Technology, Bogor Agricultural University tahun 1995, S1 Food Technology \& Human Nutrition, Universitas Djuanda, Bogor tahun 1998, S2 Food Science, Bogor Agricultural University tahun 2002 dan Ph.D., Tohoku University tahun 2007, Postdoctoral Fellow, Tohoku University tahun 2012. 
Halaman ini sengaja dikosongkan 